International Research Journal of Management, IT \& Social Sciences
Available online at https://sloap.org/journals/index.php/irjmis/
Vol. 7 No. 6, November 2020, pages: 86-95
ISSN: 2395-7492
https://doi.org/10.21744/irjmis.v7n6.1018

\title{
Causes of Interpersonal Conflict and Biparti Institution Contribution in Handling Conflict towards Tourism Industry
}

\author{
Kadek Januarsa Adi Sudharma ${ }^{a}$ \\ Putri Ekaresty Haes ${ }^{\text {b }}$
}

Article history:

Submitted: 27 August 2020

Revised: 09 September 2020

Accepted: 18 October 2020

\section{Keywords:}

hospitality industry; interpersonal conflict; leadership style; organizational communication; Biparti institution;

\begin{abstract}
This article contains the results of interpersonal interactions that occur in the tourism industry. This research is a qualitative study using three data collection techniques, namely observation, interviews, and documentation. The following data retrieval results produce the final results about the causes of interpersonal conflict in the tourism industry, namely (1) differences in the meaning of information to cause discrepancies in the work done, (2) the influence of priorities from tourists. This personal characteristic is caused by the self-concept formed in a person, (3) Unresolved old conflicts so that a compilation of new interpersonal conflicts occurs, old conflicts also contribute. (4) Interpersonal conflict also arises because the leadership style that is applied so that it causes discomfort in work which in the end the work productivity does not decrease.
\end{abstract}

International research journal of management, IT and social sciences (C) 2020.

This is an open access article under the CC BY-NC-ND license (https://creativecommons.org/licenses/by-nc-nd/4.0/).

Corresponding author:

Kadek Januarsa Adi Sudharma,

Universitas Pendidikan Nasional, Denpasar, Indonesia.

Email address: januarsa.adi@undiknas.ac.id

a Universitas Pendidikan Nasional, Denpasar, Indonesia

Universitas Pendidikan Nasional, Denpasar, Indonesia 


\section{Introduction}

Communication plays a role in human life, communication helps people to recognize themselves, others, and their environment. Human curiosity always forces them to carry out the process of communication with others. One communication process occurs in an organization. Torp (2015), explained organizational communication as comprising everything an organization speaks and does as well as everyone who is affected by the existence and activities of the organization. Self (2015), stated organizational communication is seen to be dialogic, dedicated to building relationships, understanding, and authentic debate through discourse or dialogue in the public sphere. The process of communication within an organization becomes an important thing to do because with good communication a leader can motivate his/her subordinates to do work following their duties and responsibilities following predetermined standards. Communication can also control the behavior of members of the organization through policies made by the organization.

The communication process in the organization takes place in two ways (two ways traffic communication), which is a reciprocal communication process between the management and employees, the two-way communication process will facilitate coordination and delegation of authority and duties within the organization both in the external environment and the environment internal organization (member organization, organizational culture, and organizational management). The internal environment of the organization is closely related to human resource management, namely managing people in an organization because human resources (HR) are human capital which is very important for an organization that must be managed properly to increase organizational productivity.

Good management of human resources (HR) can also minimize the appearance of disputes or disputes in industrial relations. One form of industrial relations is the tourism industry which is synonymous with customer satisfaction. There are many types in the tourism industry, namely food and beverage, lodging-accommodation, travel and tourism, events, and others. Suwena \& Widyatmaja (2010), stated the existence of the tourism industry cannot be separated from its four production factors, namely natural resources, capital, manpower, and skills. Bali is already well-known as a tourism destination, natural conditions, cultural uniqueness, and customs of their people are special characteristics for Bali, one of the Bali areas which have the largest tourism industry in Badung Regency. Badung Regency consists of six sub-districts, each sub-district has its tourism attractions according to its natural geographical location.

The tourism industry is the sector that absorbs the most labor in Bali. This industry is labor-intensive. Relationships between superiors and subordinates, employees, and customers can trigger disputes. Also, leadership style, stress, and pressure at work can trigger the emergence of interpersonal conflicts in this industry. Disputes that occur in industrial relations (industrial relationship) is a reflection of the existence of two differences in interests, namely the interests between the management of the organization and the interests of the workers. Disputes that occur in organizations are caused by many things, among others differences in personal interests and in work units, differences in the meaning of information (data), and relationships between individuals that are not good. One of the conflicts that occur in industrial relations is interpersonal conflict.

Interpersonal conflict is a dispute that occurs because of the behavior of someone who is not good (bad) in the organization. An interpersonal conflict that is not resolved immediately will cause stress and frustration. It can reduce work productivity and threaten the survival of a company. Therefore, it is important for management to always ease tensions between employees disputes occurred can be resolved properly. Various attempts were made to create stable relations between management and workers in industrial relations, one of which was the establishment of a Biparti cooperation institution based on the Regulation of the Minister of Manpower and Transmigration of the Republic of Indonesia No. 32/Men/XII/2008. Biparti cooperation institutions are communication and consultation forums on matters relating to industrial relations in one company. Members of this institution consist of employers and trade unions/labor unions that have been registered at the agency responsible for manpower affairs or workers/laborers.

The existence of Biparti cooperation institution becomes very important as a forum for resolving disputes that occur in the tourism industry. From this background, this study is to describe the resolution of interpersonal conflicts in the tourism industry that occurred in the Badung Regency.

\section{Literature review \\ Definition of Conflict in Organization}

De Dreu \& Gelfand (2008), defined conflict as a process that begins when an individual or group perceives differences and opposition between itself and another individual or group about interests and resources, beliefs, values, or practices that matter to them. Robbins (2005) cited in Thakore (2013), has defined as a process that begins where one party

Sudharma, K. J. A. ., \& Haes, P. E. . (2020). Causes of interpersonal conflict and biparti institution contribution in handling conflict towards tourism industry. International Research Journal of Management,

IT and Social Sciences, 7(6), 86-95. https://doi.org/10.21744/irjmis.v7n6.1018 
perceives that another party has negatively affected, or it is about negatively affected something that the first party cares about. Coser (1967) cited in Omisore \& Abiodun (2014), defined conflict, namely the clash of values and interests, the tension between what is and what some groups feel ought to be. Corwin (1969) cited in Chaudhry \& Asif (2015), conceptualized conflict as some form of interpersonal or intergroup strains, or as actions (for example disputes and information distortions) that violate the norms of cooperation within the organization. Provided another definition of conflict, namely a condition at the workplace that includes the misunderstanding or miscommunication among the employees of the organization due to the actual or the perceived contradiction of the needs, interests, and values. It can be stated that conflicts in organizations arise when differences occur between individuals with each other or between certain groups in conflicting organizations.

\section{Interpersonal Conflict in Organization}

Putnam \& Wilson (1982) in Barki \& Hartwick (2001), defined interpersonal conflict as content-oriented differences of opinion that reduce in interdependent relationships and can develop into incompatible goals and interests. Wall \& Callister (1995) cited in Barki \& Hatwick (2001), a process in which one party perceives that its interests are opposed or negatively affected by another party. Whereas, Hocker \& Wilmot (2014), defined interpersonal conflict as an expressed struggle between at least two interdependent parties who perceive incompatible goals, scarce resources, and interference from the other parties in achieving their goals. Kellermann \& Shea (1996) in Bao et al. (2016), believed interpersonal conflict can be simply described as a clash between two individuals who are unwillingly or unable to fulfill the expectations of each other. Interpersonal conflict refers to the representation of incompatibility, disagreement, or difference between two or more interacting individuals.

\section{Causes of Interpersonal Conflict}

Jimmieson, Tucker \& Campbell (2017), concluded interpersonal conflict in the workplace occurs because of the delegation of tasks from superiors to employees, in addition to the mismatch of an individual's role in the work environment and changes that occur in organizations become the cause of interpersonal conflict. Hight et al. (2019), concluded interpersonal conflicts occur because of poor manager characteristics that cause dissatisfaction at work. The characteristics of poor managers include unprofessional, autocratic, leadership, and management styles that are not good, not polite, delegating tasks, and making inappropriate decisions.

Lolli (2013), stated poor communication in organizations causes interpersonal conflict. Mukolwe \& Ogucha (2016), stated interpersonal conflicts in the workplace occur because of relationships at different hierarchical levels (vertical interpersonal conflicts) or the same hierarchy level (horizontal), data obtained from research conducted states that $17 \%$ of employees (subordinates) have conflicts with the manager level, $30 \%$ conflict with supervisors, $43 \%$ conflict with coworkers in one section and $64 \%$ conflict with workers who are in another section and $35 \%$ conflict with coworkers who have a lower hierarchy.

\section{Materials and Methods}

The method used in this research is a qualitative method with a case study approach. The qualitative approach is used to produce narrative descriptions of the behavior or experiences of workers who have conflicted in the internal environment of the tourism industry, through the analysis of case studies that focus on the phenomena examined in real-life situations. While the study analysis used is a single instrument case study that will use several cases of internal conflicts that occur in the tourism industry in Bandung Regency to illustrate issues related to conflict resolution by the Biparti Work Institute

Primary data collection techniques are done by observation, namely, by coming and seeing directly to the location of the study as well as to some precise that can help in providing information related to the problems to be studied, the second data collection technique is in-depth interviews with research informants conducted by purposive sampling by classifying informants into two, namely the main informant and supporting informants using in-depth and structured interview techniques, using interview guides that have been prepared in advance. The main informant in this study is the Biparti Work Institution found in several tourism industries in Badung Regency, the determination as the main informant is because the Biparti Work Institution is an internal organization that knows the conflicts that occur in every tourism organization. 
3 Results and Discussions

\subsection{Complexity of the tourism industry}

The tourism sector has become excellent for Indonesia. In addition to the main function as a foreign exchange miner, tourism is also a mainstay and potential sector to be developed. The government has committed to making tourism one of the sectors driving the national economy. Tourism development in Indonesia refers to Law No. 10/2009 concerning tourism, where tourism is organized in line with efforts to (1) increase economic growth and people's welfare; (2) tackling unemployment and eliminating poverty; (3) preserving nature, the environment, and resources; (4) promoting culture, elevating the image of the nation, and strengthening friendship between nations; and (5) fostering a sense of love for the motherland, strengthening national identity and unity.

Tourism in Indonesia continues to experience development in Bali. The cultural uniqueness and natural beauty of Bali are still an attraction for tourists both foreign and domestic tourists. One of the regencies in Bali that has the most tourism destinations in the Badung Regency. Administratively, the regency is divided into six districts, namely: Petang, Abiansemal, Mengwi, Kuta, North Kuta, and South Kuta. The tourism centers are the South Badung area which consists of Kuta, North Kuta, and South Kuta. The capital of the Badung Regency is Mangupura, which has the fifthlargest area in Bali after Karangasem Regency. The extent is only $418.52 \mathrm{~km}^{2}$ or about $7.43 \%$ of the total Bali area. Badung has a variety of areas, ranging from coastal nature to mountainous nature, so the Badung Regency region has a very complete tourist destination including waterfalls and monkey forests.

The natural beauty and cultural uniqueness of the Badung regency are also supported by the development of industries related to tourism. The scope of the tourism industry in Badung regency includes restaurants, lodging, travel agents, transportation, recreational facilities, and tourist attractions. The large scope of the tourism industry makes tourism a labor-intensive industry. People with different backgrounds are required to work together to achieve organizational goals. The bigger the tourism industry, the more complex the problems faced. The complexity that occurs in organizations embraces many things such as the flow of information and communication, the delegation of duties and authority, and decision-makers. Also, the complexity in managing different human resources has the potential to cause conflict because various organizational resources come from different backgrounds who have different goals and motivations at work.

Conflicts that occur in organizations will disrupt the relationships between individuals in the organization, an uncomfortable working atmosphere will reduce work motivation so productivity will also decrease. Disputes that occur in an organization or company can be caused by many things, among others due to values or norms, data or information, relationships, structural, differences in interests, status, and personal role or between work units.

According to Liliweri (2014), the potential for conflict will always be anytime and anywhere, one of which is the conflict of interpersonal relations, namely conflicts that occur when interpersonal relations within an organization are disturbed, disruptions occur when there are differences in interpersonal relationships with personal needs and desires that should be fulfilled by the organization. Interpersonal conflicts that are not immediately resolved will turn into conflicts between groups or units (Wood \& Bell, 2008; Berg et al., 1998). Furthermore, Liliweri (2014), stated relationship conflict between units is a conflict between one work unit with other work units in the organization that occurs when relations between work units within an organization are disrupted.

\subsection{Causes of tourism industry conflict}

This study aims to reveal the causes of interpersonal conflict in the tourism industry.

1. Communication Failure

In the tourism industry, interpersonal conflict occurs because the failure of two parties (workers and management or between units) in conveying thoughts, ideas, feelings, and actions becomes the cause of not achieving the same meaning (mutual understanding) so that it creates a wrong perception between the two the party. The cultural and educational background of the workers, as well as the non-opening of communication channels in the organization, are the main causes so that workers have different perceptions about information. For this reason, it is necessary to build a good communication channel in an organization, because communication workers build relationships with other workers so that the needs and goals of the organization are achieved. In organizational communication is a viral thing that can motivate each member of the organization, effective communication will create good cooperation so that organizational goals can be achieved. Robbin \& Judge (2013), stated six things can cause communication to be ineffective, namely:

Sudharma , K. J. A. ., \& Haes, P. E. . (2020). Causes of interpersonal conflict and biparti institution contribution in handling conflict towards tourism industry. International Research Journal of Management, IT and Social Sciences, 7(6), 86-95. https://doi.org/10.21744/irjmis.v7n6.1018 
a) Filtering

The first obstacle in communication is filtering. Filtering is a communication process where not all information is conveyed. Only information that was deemed necessary and beneficial was conveyed. But if the information will bring harm then the information is not complete or even not delivered at all. The main reason for filtering is due to the number of levels in the organizational structure. In some cases of conflict in the tourism industry, the process of filtering this information becomes an obstacle because not all information is conveyed by management to employees so that employees only guess at the situation that occurs in the organization. The inability of subordinates to convey the message above caused the lack of information channels to open between management and employees. Also, the many bureaucratic flows of information cause the process of filtering information into obstacles in the organization.

b) Selective Perception

The selectivity in receiving messages in the organization's communication process is also a problem in the organization, the process of message selectivity is influenced by several things, including needs, motivation, experience, background, and other personal characteristics. In some cases of interpersonal conflict, some people in the organization both superiors and subordinates will only listen to messages relating to themselves and often ignore other messages.

c) Overload Information

In the process of communication sometimes a person adds or subtracts information obtained and conveyed. This is because a person's capacity to process data is limited. So, when the information received by someone exceeds the capacity that they can sort and use, people will tend to select, ignore, pass, or forget the information or stop processing until the excess situation passes. In tourism organizations this often happens, this is caused by cultural factors, educational background, and individual dislikes. Like chains, the longer the chain, the more information can be increased or even reduced so that it is the core of the message is biased and the resulting feedback is also not the same as the conveyed message.

d) Emotions

Emotions felt by someone can affect the communication process of the organization. In some cases, it was revealed that personal problems also become obstacles for someone in communication. This personal problem is closely related to one's emotions, when someone is angry, sad, or happy then the communication process will be different.

e) Language

In the language we use every day, often some words can contain many meanings when spoken. Age, education, and cultural background are three variables that greatly affect the language a person uses and the definition given to those words. An organization usually consists of different members, both educational background, culture, and age so that the use of language is different. The sender of the message or information tends to assume that the words and terms they use are the same, both for themselves and for the recipient of the information. In the tourism industry, the use of this language is an obstacle caused by different cultural backgrounds, people with cultural roots work in this industry even though they come from the same culture, namely Bali, way of speaking, choice of words, voice intonation in conveying messages become obstacles in communication.

f) Anxiety

5 to $20 \%$ of communication failures are caused by fear and anxiety. People with this level of anxiety experience difficulty in communicating both verbally, in writing, and both. These people may find it very difficult to talk to other people directly or become very anxious when they have to use the telephone, rely on memos or e-mail. In the tourism industry, this anxiety arises in new employees, they are still afraid when they have to deal with work tasks, this is caused by fear of making mistakes in work.

g) Lies

The final obstacle to effective communication is the presentation of incorrect information. Conveying information or greeting data within the organization becomes fatal because the data will be related to the steps that will be taken by the next management. Several cases in the tourism industry were found that workers who were found to be falsifying data were cracked down on by management.

Effective communication has a positive impact on performance, job satisfaction, and commitment as revealed by Newsroom (2011), stated effective communication, communication tends to encourage better performance and job 
satisfaction and feel more involved in work. This is evident in the loyalty of employees in the organization where they work when employees feel valued, the higher their loyalty and commitment to work.

Inequality of meaning in the communication process is also caused by different characteristics of the actors of the conflict. A person's characteristics are motivated by the self-concept formed by that person. Self-concept is a person's perspective about himself/herself. Someone can develop their self-concept depending on the desires from within themselves and the surrounding environment. A person's self-concept can be positive and negative. Some research informants explained that interpersonal conflicts that occur make them frustrated but there is no desire to resolve the conflict because of pride (ego). Positive self-concept will have a good impact on a person, on the contrary negative self-concept according to Modupe (2020), can cause anxiety, frustration, and even depression. Several components make up the concept of self, namely identity, body image, self-esteem, and role performance. These five things form the characteristics of a person both as a leader and worker.

1. Unresolved Old Conflicts

Interpersonal conflict arises because the problem has not been resolved in the past, so the parties to the conflict reopen the dispute. Unresolved disputes can trigger greater conflict, for this reason, it is important to resolve disputes thoroughly. They do not become the seeds of disputes in the future. Conflicts that are not resolved properly can also trigger stress at work, workers become lazy to provide good service to customers. From the results of data collection, this is still commonly found in the tourism industry, in some cases, people in conflict have made peace with their opponents but have not resolved the conflict so they don't talk to each other. This will certainly have an impact on the organizational climate. Poole (1985) in Liliweri stated organizational climate is closely related to organizational communication because in communication it describes the situation of relations between humans in organizations. An uncomfortable working environment, in addition to having a bad impact on work productivity also increases stress on the work environment. The interpersonal conflict that is not immediately resolved will be a big conflict because each individual who has a conflict has a group so that interpersonal conflict will turn into group conflict.

Liliweri (2014), stated the stages of conflict are as follows starting with (1) pre-conflict, namely the initial situation of conflict, the situation that sparked, the initial mismatch of needs, values, perceptions, power, and feelings between the two parties after it entered into the stage, (2) confrontation that is increasingly open conflict, marked by open statements or expressions about differences in needs, perceptions, power, values, and feelings between two parties, (3) crisis namely actions or physical violence (aggressive) due to different needs, perceptions, power, values , and feelings between two parties, (4) the result is the development of relations between the two parties, tense, calm, negotiation, mediation, oppression, surrender, etc. The last stage is (5) post-conflict, namely the last situation after the management process. When the conflict is still at an early stage, the parties involved in the conflict must find a way out so that the post-conflict organizational environment can return to normal. From the level of conflict described by Liliweri, several cases that occurred in the tourism industry have reached a crisis, namely acts of violence that lead to termination of employment.

2. Leadership Style

Also, interpersonal conflicts that occur in the tourism industry are caused by leadership style. Al Khajeh (2018), stated leadership style influences culture and organizational performance. Rivai (2014), stated leadership style is a characteristic or strategy used by a leader to influence his subordinates. In the tourism industry, leadership becomes very important, because good leadership will easily lay the foundation of trust in its members, and vice versa if you have a leader who is not good then the goals of the organization will not be achieved. The quality of a leader can encourage its members to get successful careers.

In the tourism industry, several leadership styles are used, namely authoritarian type, this leadership style is a style that does not allow others to participate in decisions made. This leadership style makes its own decisions without asking for opinions, suggestions from subordinates, when in fact subordinates understand very well the conditions in the field (McColl-Kennedy \& Anderson, 2002; Lyons \& Schneider, 2009; Putra \& Rasmini, 2018). The second leadership style is charismatic, this leader figure usually has many admirers, and although sometimes the decisions made are not wise their subordinates respect them. Based on the results of the interview, this leadership style is based on the physical form of the leader, the persuasive style that they have, and their skill in processing words. Pseudo-democratic leadership style, which is a leader who opens the room for their subordinates to have an opinion but is pseudo because they have their own opinion. The last leadership style that is used is a democracy, leaders with this style open the widest opportunity for subordinates to argue, and develop themselves.

Sudharma , K. J. A. ., \& Haes, P. E. . (2020). Causes of interpersonal conflict and biparti institution contribution in handling conflict towards tourism industry. International Research Journal of Management, IT and Social Sciences, 7(6), 86-95. https://doi.org/10.21744/irjmis.v7n6.1018 
Based on the results of data collection it was revealed that organizations/companies engaged in the tourism industry have good leaders, but some cases also reveal that leaders are less able to protect their members. A good leader is a leader who has a positive impact on the surrounding organizations and communities. Furthermore, Lussier (2002) in Kaswan (2017), stated the quality of leadership can encourage someone to have a successful and happy career, in other words, workers need good leaders to increase productivity and work skills. Kaswan (2017), stated two essential elements that need to be underlined contained in the concept of leadership, namely influence, and interpersonal relationships. The ability to influence and establish interpersonal relationships with groups or teams that are led to determine the success of a leader. The conflict caused by organizational leaders will result in poor relations between superiors and subordinates so that the process of upward communication becomes ineffective, subordinates are reluctant to respond to their leaders.

\subsection{Biparti Cooperation Institute}

Interpersonal conflicts that occur in the tourism industry can be resolved properly in a consensus agreement. If the dispute cannot be resolved, it will be brought to Biparti Cooperation Institute. It is an institution that aims to create an atmosphere of effective organizational communication and a conducive work climate.

It is regulated in Article 106, the Law of the Republic of Indonesia No. 13/2003 concerning Manpower which requires that every company employing 50 workers/laborers or more is obliged to form Biparti functions as a communication forum, and consultation on employment matters in the company. Membership is following the Decree of the Minister of Manpower and Transmigration of the Republic of Indonesia No. Kep.255/Men/2003 Concerning the Formation and Composition of Biparti Cooperation Institution Membership, a collaboration of elements of employers and workers, so that interpersonal conflicts that occur within organizations can be resolved by consensus in this institution if it cannot be resolved privately.

As it functions as a communication and consultation forum for workers and employers, it has the following duties (1) conducting meetings periodically and or at any time if needed, (2) communicating employer policies and aspirations of workers/laborers to prevent industrial relations problems in the company, (3) delivering suggestions, considerations and opinions to employers/workers and/or trade unions in the context of establishing and implementing company policies. The purpose of the Biparti cooperation forum is important to improve social dialogue that is designed to include the entire agenda of activities, both regarding the types of negotiations or the short exchange of information between employers, worker/labor representatives, and the government regarding the problems of common interests relating to economic and social policies.

The dispute resolution mechanism through Biparti following the Law of the Republic of Indonesia No. 2/2004 Concerning Industrial Relations Disputes, requires that any industrial relations disputes must first be resolved through Biparti negotiations between employers and workers within thirty days of work counted from the date the negotiations began. Within thirty working days if one of the parties refuses to negotiate or the negotiations have been made, but the agreement is not reached, the Biparti negotiation is deemed to be a failure so that one party or both parties are required to register their dispute with the agency responsible for local employment with enclosing evidence that Biparti settlement efforts have been made. After receiving a record from one of the parties, the agency responsible for local employment must offer the parties to agree on choosing a settlement through conciliation or arbitration. If the parties do not determine a settlement option through conciliation or arbitration within seven days, the agency responsible for local manpower is delegated to settle the dispute through the mediator. Each Biparti negotiation must be made a treatise consisting of the full name and full address of the parties, the date and place of the negotiation, the subject matter and reason for the dispute, the opinion of the parties, conclusions or the outcome of the negotiations as well as the date and signature of the parties to the negotiations. In the case of deliberations as intended to reach a settlement agreement, a joint agreement is signed by the parties. The joint agreement is binding and becomes law and must be implemented by the parties and must be registered by the parties who agreed with the Industrial Relations Court at the District Court in the territory of the parties entering into a joint agreement.

\section{Conclusion}

An interpersonal conflict that occurs in the tourism industry is caused by several things, namely the mismatch of meaning between the communicator and the recipient of the message, giving rise to different perceptions. These different perceptions eventually lead to different actions and reactions so that the purpose of sending information 
becomes biased. The second cause is the different individual characteristics that exist in the tourism industry, these personal characteristics are shaped by the individual's self-concept. Interpersonal conflict arises when conflicts in the past do not get resolved so that it becomes boomerang when disputes occur in the future. The last cause is the lack of a good leadership style so that it causes discomfort at work.

\section{Conflict of interest statement}

The authors declared that they have no competing interests.

\section{Statement of authorship}

The authors have a responsibility for the conception and design of the study. The authors have approved the final article.

Acknowledgments

We are grateful to two anonymous reviewers for their valuable comments on the earlier version of this paper.

Sudharma, K. J. A. ., \& Haes, P. E. . (2020). Causes of interpersonal conflict and biparti institution contribution in handling conflict towards tourism industry. International Research Journal of Management,

IT and Social Sciences, 7(6), 86-95. https://doi.org/10.21744/irjmis.v7n6.1018 


\section{References}

Al Khajeh, E. H. (2018). Impact of leadership styles on organizational performance. Journal of Human Resources Management Research, 2018, 1-10.

Bao, Y., Zhu, F., Hu, Y., \& Cui, N. (2016). The research of interpersonal conflict and solution strategies. Psychology, 7(04), 541.

Barki, H., \& Hartwick, J. (2001). Interpersonal conflict and its management in information system development. MIS quarterly, 195-228.

Berg, C. Z., Shapiro, N., Chambless, D. L., \& Ahrens, A. H. (1998). Are emotions frightening? II: An analogue study of fear of emotion, interpersonal conflict, and panic onset. Behaviour Research and Therapy, 36(1), 3-15. https://doi.org/10.1016/S0005-7967(97)10027-4

Chaudhry, A. M., \& Asif, R. (2015). Organizational Conflict and Conflict Management: a synthesis of literature. Journal of Business and Management Research, 9, 238-244.

Corwin, R. G. (1969). Patterns of organizational conflict. Administrative Science Quarterly, 507-520.

Coser, L. A. (1967). Continuities in the study of social conflict.

De Dreu, C. K., \& Gelfand, M. J. (2008). Conflict in the workplace: Sources, functions, and dynamics across multiple levels of analysis.

Hight, S. K., Gajjar, T., \& Okumus, F. (2019). Managers from "Hell" in the hospitality industry: How do hospitality employees profile bad managers?. International Journal of Hospitality Management, 77, 97-107. https://doi.org/10.1016/j.ijhm.2018.06.018

Hocker, J. L., \& Wilmot, W. W. (2014). Interpersonal conflict. New York: McGraw-Hill.

Jimmieson, N. L., Tucker, M. K., \& Campbell, J. L. (2017). Task conflict leads to relationship conflict when employees are low in trait self-control: Implications for employee strain. Personality and Individual Differences, 113, 209218. https://doi.org/10.1016/j.paid.2017.03.035

Kaswan, M. (2017). Mengembangkan Perilaku Produktif dan Mewujudkan Kesejahteraan Pegawai di Tempat Kerja. Psikologi Industri \& Organisasi, 192-238.

Kellermann, K., \& Shea, B. C. (1996). Threats, suggestions, hints, and promises: Gaining compliance efficiently and politely. Communication Quarterly, 44(2), 145-165.

Keputusan Menteri Tenaga Kerja Dan Transmigrasi Republik Indonesia Nomor : KEP.255/MEN/2003 Tentang Tata Cara Pembentukan Dan Susunan Keanggotaan Lembaga Kerjasama Biparti

Ketut, S. I., \& Widyatmaja, I. G. N. (2010). Pengetahuan Dasar Ilmu Pariwisata. Denpasar: Udayana University Press. Undang-Undang Republik Indonesia Nomor, 10.

Liliweri, A. (2014). Sosiologi dan komunikasi organisasi. Jakarta: Bumi Aksara.

Lolli, J. C. (2013). Interpersonal communication skills and the young hospitality leader: Are they prepared?. International journal of hospitality management, 32, 295-298. https://doi.org/10.1016/j.ijhm.2012.02.010

Lussier, D., \& Chen, J. (2002). Material characterization of woven fabrics for thermoforming of composites. Journal of Thermoplastic Composite Materials, 15(6), 497-509.

Lyons, J. B., \& Schneider, T. R. (2009). The effects of leadership style on stress outcomes. The Leadership Quarterly, 20(5), 737-748. https://doi.org/10.1016/j.leaqua.2009.06.010

McColl-Kennedy, J. R., \& Anderson, R. D. (2002). Impact of leadership style and emotions on subordinate performance. The leadership quarterly, 13(5), 545-559. https://doi.org/10.1016/S1048-9843(02)00143-1

Modupe, O. O. (2020). Effective Adaptation of Music Intervention in the Psychological Management of Late Life Depression in Nigerian Communities. Clinical Medicine Research, 9(5), 103.

Mukolwe, E., \& Ogucha, B. E. (2016). Uncovering the Hidden Costs of Interpersonal Conflicts: A Study of Selected Hotels in Kenya. Journal of Tourism, Hospitality and Sports, 17, 2312-5187.

Newsroom, J. W. (2011), Organizational Behavior, Human Behavior at work, New York:Mc-GrawHill

Poole, D. (1985). On the Comparison of Theories: Preferring the Most Specific Explanation. In IJCAI (Vol. 85, pp. 144-147).

Putnam, L. L., \& Wilson, C. E. (1982). Communicative strategies in organizational conflicts: Reliability and validity of a measurement scale. Annals of the International Communication Association, 6(1), 629-652.

Putra, I. M. E. L., \& Rasmini, N. K. (2018). Style of leadership and organizational culture as moderator of influence of competence and internal control system towards report quality. International research journal of management, IT and social sciences, 5(3), 22-34. 
Rivai, V. (2014). Manajemen Sumber Daya Manusia untuk Perusahaan, Edisi ke 6, PT. Raja Grafindo Persada, Depok, 16956.

Robbin, S. P., \& Judge, T. A. (2013). Organizational behavior (Vol. 15).

Robbins, S. P. (2005). Principles of organizational behavior. Translated by Parsaeian A, Arabi M. Ninth printing. Publications Cultural Research Bureau in Tehran.

Self, P. (2015). Econocrats \& the Policy Process: The Politics \& Philosophy of Cost-Benefit Analysis. Macmillan International Higher Education.

Thakore, D. (2013). Conflict and conflict management. IOSR Journal of Business and Management (IOSR-JBM), 8(6), 07-16.

Torp, S. M. (2015). The strategic turn in communication science (pp. 35-53). New York, Routledge.

Undang-Undang Republik Indonesia Nomor 13 Tahun 2003 tentang Ketenagakerjaan

Undang-Undang Republik Indonesia Nomor 2 Tahun 2004 Tentang Penyelesaian Perselisihan Hubungan Industrial

Wall Jr, J. A., \& Callister, R. R. (1995). Conflict and its management. Journal of management, 21(3), 515-558.

Wood, V. F., \& Bell, P. A. (2008). Predicting interpersonal conflict resolution styles from personality characteristics. Personality and individual differences, 45(2), 126-131. https://doi.org/10.1016/j.paid.2008.03.010

Sudharma , K. J. A. ., \& Haes, P. E. . (2020). Causes of interpersonal conflict and biparti institution contribution in handling conflict towards tourism industry. International Research Journal of Management,

IT and Social Sciences, 7(6), 86-95. https://doi.org/10.21744/irjmis.v7n6.1018 